\title{
Baltimaade üldlaulupidude laulutraditsioonid ja pärand ${ }^{1}$
}

\begin{abstract}
Guntis Šmidchens
Teesid: Artiklis uuritakse, milline on Eesti, Läti ja Leedu 70 üldlaulupeol kõlanud kogu repertuaari - 1973 laulu - esitamistraditsioon. Enamik lauludest (74-84\%) on innovatsioonid, lauldud vaid ühe peo kavas. Traditsioonilised laulud - need, mida korratakse kahel või rohkemal peol - ja eriti need laulud, mida korratakse erinevatel ajastutel, ongi saanud laulupidude pärandiks. Pidude korraldajatel on kava valimisel käed vabad: peol saab laulda palju vanu laule, aga saab ka laulda 98\% uut repertuaari, nagu oli Eestis 1928. aastal. Selline ongi laulupidude laulukava valimise pärand.
\end{abstract}

Märksõnad: laulud, laulupeod, pärand, traditsioon

Ameerika Folkloori Seltsi (AFS) 2015. aasta konverentsil märkis John Szwed, et viimasel ajal olevat teadlased palju uurinud seda, mida inimesed räägivad lauludest, kuid liiga vähe on uuritud laule ja laulmist (Szwed 2015). Niisiis saab laulupeo tervikut - kombeid, materiaalset ja suulist traditsiooni - lugeda kui ühte teksti. Käesolevas artiklis vaatlen aga ainult Baltimaade 70 üldlaulupeo (26 Eesti, 25 Läti ja 19 Leedu) repertuaari: 893 Eesti, 646 Läti ja 434 Leedu laululaval lauldud laulu. ${ }^{2}$ Need laulud ongi laulupeo põhisisu (Jürgenson 2014: 85). Mind kui folkloristi huvitab selles laulukorpuses laulutekstide traditsioon "see, mis jätkub aga muutub" (Wilgus 1973: 245). Kui taasesitamisele tulevad laulud varasematest peokavadest, on traditsioon konservatiivne, kui seevastu ilmuvad kavasse uued tekstid, on traditsioon innovatiivne. Huvi suureneb veelgi, kui märgitakse, et tänapäeva laululaval seisab korraga 16000 lauljat, kes jälgivad professionaalset dirigenti ja trükitud noodivihikutes professionaalsete heliloojate loodud noote: nüüdismaailmas elavad traditsioonid kiiremini, laiemalt ja tugevamalt kui kunagi varem, kuid alles on laule nautivad inimesed, kes kordavad vanu laule ja leiutavad uusi (Dégh 1994; Bausinger 1990). Kes nad on? Milline on laulude kordamise ja loomise traditsioon? Ja milline on tüüpiline laulupeolaul? Põhimõtteliselt on tüüpiline korratud laul. Laulupidude 
traditsiooni kui terviku kõige representatiivsemad laulud on need, mida on korratud erinevatel ajastutel, sest need on erinevate põlvkondade käest vastu võetud kui pärand.

\section{Traditsioon ja selle aktiivsed kandjad: lauljad, dirigendid, heliloojad}

2015. aasta sügisel esitas Valdis Muktupāvels (2015) Balti uuringute konverentsil Marburgis detailse nimekirja, milliseid läti laulupeotraditsioone on aja jooksul muudetud (näiteks rahvariiete kandmine) ja milliseid on korratud igal peol algusest peale (näiteks rongkäik - mis jäi Lätis ära ainult 1926. aastal). Eesti nimekiri oleks nähtavasti umbes sama. Teame, et laulupeokoori traditsioonides on toimunud palju muutusi. Näiteks on Eesti laulupeokoori algne nägu teisenenud: Tartus laulsid 1869. aastal 800 meest, enamik nendest kooliõpetajad; hiljem tulid juurde naised, pärast ka lapsed, vaheldumisi on külla tulnud soome, läti, kaevurite, sõdurite jm koorid. Teame, et Balti laulupidude kõige suurem lauljate arv - 30525 oli eelmisel aastal Eestis, ja kõige väiksem koor on samuti olnud Eestis- 586 lauljat kolmandal laulupeol. Aga üldine pilt on selline, et lauljate arv ja koosseis on pooleteise sajandi jooksul muutunud, kasvanud või kahanenud aastast aastasse. Mõningast stabiilsust annavad veteranlauljad, kes on laulnud varasematel pidudel, samuti laulupeo traditsiooni kokkusulamine hõimude traditsioonidega, kus perekonna mitmed põlvkonnad on peost osa võtnud nii lauljate kui ka pealtvaatajatena (Lauristin 2014: 58-61; Gudelis 2001: 224-225; Lak̦e 2014: 15, 17).

Huvitav on otsida traditsioonilisi jooni ka dirigentide koosseisus. Konservatiivsus on silmanähtav, kui sama dirigent on juhatanud koori rohkem kui kümnel üldlaulupeol; siin on Läti arvud kõige põnevamad: Jānis Dūmiṇš (19222011) on koorijuht olnud 13 peol; Leonīds Vīgners (1906-2001) 12; Gido Kokars (1921), Imants Kokars (1921-2011) ja Haralds Mednis (1906-2000) 11 peol; Eestis ja Leedus on 11 üldlaulupeo koori juhatanud vaid Lionginas Abarius (1929), Kuno Areng (1929) ja Konradas Kaveckas (1905-1996).

Dirigentide arv eri laulupidude ajal ei olenenud lauljate arvust; see kasvas ja mõnikord kahanes omasoodu (joonis 1). Kuni 1928. aastani juhatas tervet eesti laulupeo kontserti kolm või vähem dirigenti; tänapäeva dirigentide meeskond on kümnekordistunud, aga koor on ainult kolm korda suurem. Viimasel paarikümnel aastal muutus dirigentide koosseis dramaatiliselt: kui varem oli naisdirigente Eestis vaid kaks, ja igaüks juhatas vaid üks kord (Miina Härma 1933 ja Vaike Uibopuu 1985), siis alates 1990. aastast on juurde tulnud 17 naist. Kuidas see pidevalt laiem ja kirjum juhtide järjekord mõjutab laulupeo 

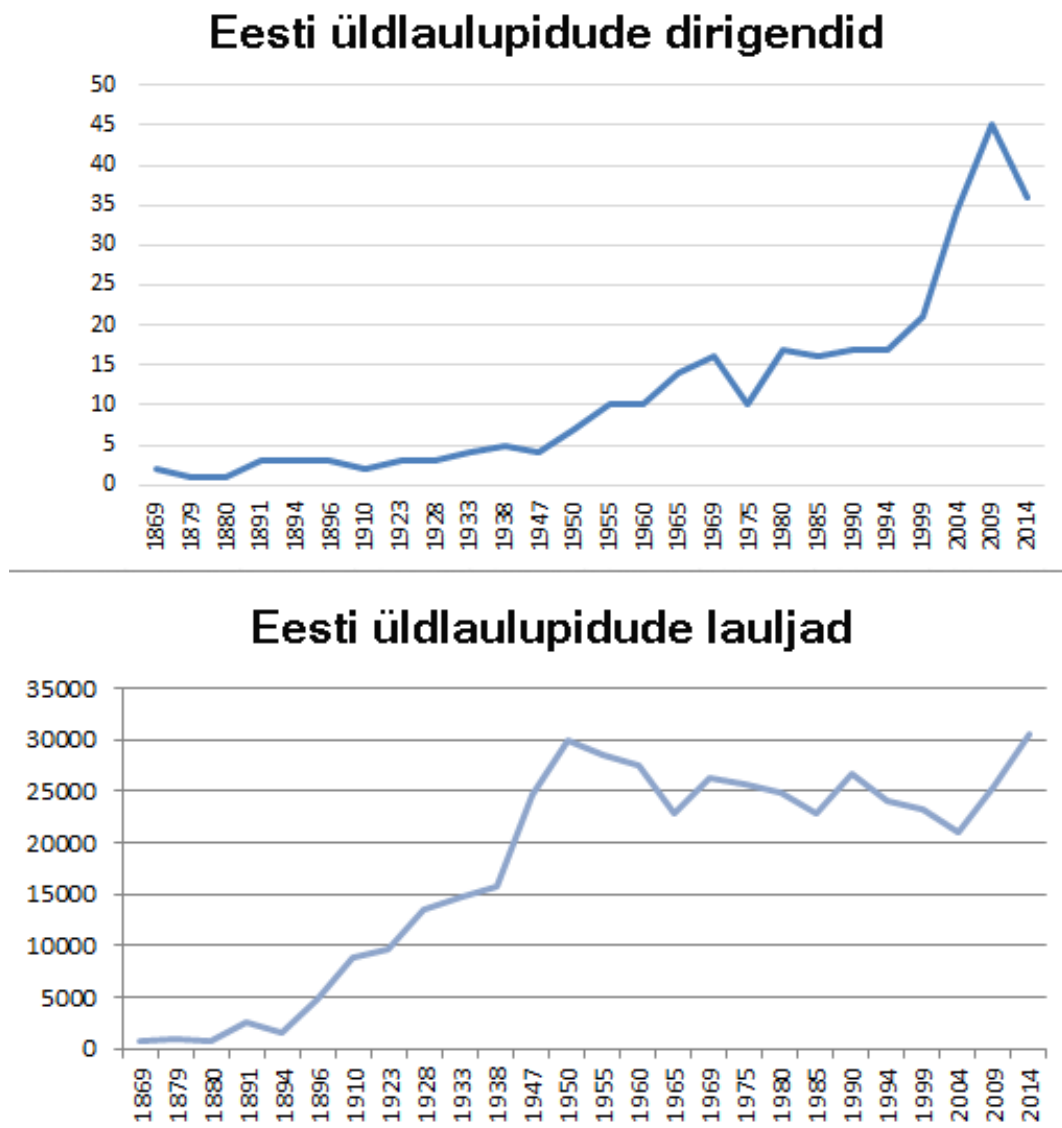

Joonis 1. Eesti üldlaulupidude dirigentide ja lauljate arvud 1869-2014.

pärandit, analüüsib nähtavasti järgmine põlvkond. Veel võib tähele panna, et laulupeo ajaloolises kontekstis on tunda dramaatilisi muutusi heliloojatest dirigentide koosseisus. Esimesel üheteistkümnel laulupeol olid peaaegu kõik (16 dirigendist 13) ka laulupeolaulude loojad, viimase peo 36 dirigendist oli heliloojaid vaid kaks (Arne Saluveer ja oma laulu kordamiseks spetsiaalselt pulti kutsutud Pärt Uusberg). Tänapäeval on muusikud muidugi kitsamalt spetsialiseerunud kui varem, mil helilooja õppis ka koori juhatama ning koorijuht õppis sageli ka kompositsiooni. Kahe elukutse eraldumise mõju laulupeo traditsioonis pole nähtavasti veel uuritud, kuid hiljuti soovitati need jälle ühendada (Jürgenson 2014: 89).

Heliloojate nimed (Eesti pidudel on neid olnud 302, Lätis 192 ja Leedus 161), korratud ja tuttavad, annavad peoprogrammidele traditsionaalset pärandipärast stabiilsust. Kõige rohkem üldlaulupeo laule - 41 (6,3\% tervest Läti 
laulupidude repertuaarist) on loonud Emilis Melngailis (1874-1954); vähemalt ühte tema laulu on lauldud alates aastast 1910 igal laulupeol, kokku 21 peol. Mitmetel läti laulupidudel on esitatud Jāzeps Vītolsi (1863-1948) laule 23 korda, kokku 29 laulu; kolmas kõige korratum lätlane on Andrejs Jurjāns (1856-1922; 27 laulu 21 ametlikus programmis). Melngailise rekordi kõrvale võib panna 40 lauluga Gustav Ernesaksa, kelle laule (4\% eesti repertuaarist) on lauldud 16 Eesti laulupeol. Kõige kestvamad eesti heliloojad on olnud Miina Härma (1864-1941), kelle 18 laulust on vähemalt ühte lauldud 22 peol (alates 1891. aastast igal peol, välja arvatud 1965) ja Mihkel Lüdig (1880-1958; 12 laulu 19 peol). Leedu laulupeo kava nurgakivideks on olnud Stasys Šimkus (1887-1943; 26 laulu - 6\% leedu repertuaarist - 13 peol), Jonas Švedas (1908-1971; 19 laulu 10 peol) ja Juozas Naujalis (1869-1934; 15 laulu 16 peol).

\section{Traditsioonilised laulud ja laulupärand minevikus}

Iga laulupeo laul jääb traditsiooniliseks: vähemalt kaks aastat enne pidu paljudes proovides ja kohalikel kontsertidel korratud, pärast pidu esitatud mitmel korral, ja nagu mulle on mitmete poolt öeldud ning nagu olen ka ise kogenud, kõlab peas sageli uuesti ja uuesti. Aga pikemas perspektiivis on enamik lauludest lühiaegsed innovatsioonid: nendest enamikku - 84\% leedu, 83\% eesti, $74 \%$ läti lauludest - on lauldud vaid ühe laulupeo programmis. See pole kuidagi konservatiivne traditsioon, ja pole ka palju laule, mida saaks nimetada tüüpiliseks. Traditsionaalsemaid laule - neid, mida on lauldud vähemalt kahel laulupeol - on eesti laulupidudel olnud 152, Lätis 170 ja Leedus 72. Aga nendest suurema osa püsimine laululaval on olnud lühiaegne. Kui jagada eesti, läti ja leedu laulupidude traditsioon nelja ajaloolisse etappi: a) tsaariaegsed laulupeod 1869-1910, b) iseseisvusaegsed laulupeod 1923-1938, c) nõukogudeaegsed laulupeod 1946-1985 ja d) taasiseseisvusaegsed laulupeod 1990-2014, pole arvatavasti vaja laiemalt selgitada, et igal ajastul on oma poliitiline eripära ja laulude kontekst (Brüggeman \& Kasekamp 2014). Leitakse, et suurt osa lauludest on korratud vaid oma ajastul; järgmisse ja ülejärgmisse ajastusse on üle kantud vaid 91 eesti, 96 läti ja 25 leedu laulu. Seda väiksemat laulukorpust tunnustavadki peost osavõtjad laulupidude kestvaks pärandiks (joonis 2).

Supertraditsioonilisi laule, mis on sobinud kõikidel ajastutel ja seega on ka kõige representatiivsemad pooleteise sajandi pikkuse laulupeotraditsiooniga laulud, on palju vähem: kaks eesti laulu (Kunileiu "Sind surmani" ja Läte "Laul rõõmule"), kuus läti ja neli leedu laulu. ${ }^{3}$ Nende 12 lauluga tuleks alustada juttu sellest, millised on balti laulupidude tüüpilisimad ja representatiivseimad laulud. Ühest küljest on siin silmapaistev erinevus uuema ja vanema traditsiooni 


\begin{tabular}{|c|c|c|c|c|c|c|c|c|c|c|c|c|c|c|c|}
\hline \multicolumn{16}{|c|}{ Traditsioonilised laulud } \\
\hline Eesti & $\ll$ & $\stackrel{\infty}{\varangle}$ & $\begin{array}{l}U \\
\infty\end{array}$ & ○్ & 足 & $\dot{\varangle}$ & $\underset{4}{O}$ & 요 & $\infty$ & $\dot{\infty}$ & తి & ம & $u$ & 8 & 0 \\
\hline $1869-1910$ & 8 & 6 & 1 & 2 & 3 & 3 & 1 & 6 & & & & & & & \\
\hline $1923-1938$ & & & & & & & & & 1 & 15 & 12 & 11 & & & \\
\hline $1947-1985$ & & & & & & & & & & & & & 44 & 31 & \\
\hline $1990-2014$ & & & & & & & & & & & & & & & 9 \\
\hline Läti & $\varangle$ & $\stackrel{\infty}{\varangle}$ & $\underset{\infty}{4}$ & Oి & 足 & $\dot{\varangle}$ & $\underset{ه}{0}$ & \& & $\infty$ & U & తి & ம & $u$ & O & 0 \\
\hline $1873-1910$ & 12 & 14 & 1 & 6 & 3 & 4 & 0 & 3 & & & & & & & \\
\hline $1926-1938$ & & & & & & & & & 3 & 5 & 14 & 12 & & & \\
\hline $1948-1985$ & & & & & & & & & & & & & 24 & 31 & \\
\hline $1990-2013$ & & & & & & & & & & & & & & & 21 \\
\hline & & & & & & & & & & & & & & & \\
\hline Leedu & & & & & & & & & $\infty$ & $\dot{\infty}$ & 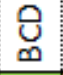 & ๑ & $u$ & 8 & 0 \\
\hline $1924-1930$ & & & & & & & & & 1 & 5 & 4 & 5 & & & \\
\hline $1946-1985$ & & & & & & & & & & & & & 19 & 11 & \\
\hline $1990-2014$ & & & & & & & & & & & & & & & 27 \\
\hline
\end{tabular}

Joonis 2. Baltimaade traditsioonilised laulud (lauldud vähemalt kahel laulupeol) erinevatel ajalooetappidel: a) tsaariaeg; b) iseseisvusaeg; c) nõukogude aeg; d) taasiseseisvusaeg.

vahel, sest tänapäeval representatiivsemateks ja tähtsamateks nimetatakse tavaliselt hoopis teisi laule - Eestis on enamiku inimeste meelest tüüpilisimad ja kõige olulisemad laulupeolaulud erinevatel ajastutel loodud Ernesaksa "Mu isamaa on minu arm" ja Lüdigi "Koit" (Lauristin 2014: 42-43). Need kaks on küll enim lauldud (mõlemad 12 laulupeol) eesti laulud, ja selles mõttes ka tüüpilised, aga siiski on neid lauldud vaid pooltel kõikidest pidudest. Koidula sõnadega laulu "Mu isamaa on minu arm" on teise viisiga lauldud ka tsaari ajal; aga seda ei lauldud esimese vabariigi ajal. Samuti on "Koiduga", mida lauldi küll ühel esimese vabariigi laulupeol, aga mitte tsaariajal. Tuleb lisada, et selles ajaloo etappide kontekstis on "Mu isamaaga" võrreldav Kappeli “Ööbik", mida on samuti lauldud tsaari-, nõukogude- ja taasiseseisvuse ajal.

Milline on nende representatiivsemate laulude sisu? On märkimisväärne, et mõlemat eelmainitud laulupaari - supertraditsioonilise Kunileiu/Läte ja tänapäeva pärandiks võetud Ernesaksa/Lüdigi puhul üks on isamaalaul ja 
teine laul laulmisest. Tüüpiline laulupeolaul, pigem tüüpilised eesti ${ }^{4}$ laulupeo laulud kuuluvad ühesse või teise kategooriasse. Sarnane fenomen on tekkinud kõige hilisema perioodi lauludes: kui viimasel laulupeol üheks emotsionaalseks kõrgpunktiks kujunes isamaalaulu "Ta lendab mesipuu poole" laulmine, siis teine samuti mõjuv hetk oli, kui koor kordas Uusbergi "Muusikat". Kumb nendest oli ja on lauljate meelest ilusam või tähtsam? Kumma kordamist sooviti rohkem? Siin sobib meenutada karupoeg Puhhi tarka vastust küsimusele, kas soovida piima või mett: mõlemat. Harjumuspärane on olnud näha laulupidu rahvusliku identiteedi kandjana, nii osalejate kui ka uurijate poolt (Kuutma 1996; Lauristin 2014: 52-55), kuid kas ei saa seda uurida ka üldise inimsoo muusikalise identiteedi kandjana? Statistiliselt laulupeo laulurepertuaari läbi lugedes paistab, et saab küll. Juhan Liivi imestus ja küsimus, kuidas on muusika inimese rinda saanud, ei ole kuidagi rahvuslik asi, kuid see küsimus on laulupeo kontserdi kaudu saanud eesti kultuuris rahvapäraseks, eesti laulja maailmavaate osaks.

\section{Tulevikupärand}

Niisiis järgnevad mõned järeldused laulupeo repertuaari matemaatilisest analüüsist: Baltimaade laulupidude laulurepertuaar on 74-84\% innovatiivne. Alates aastast 1869 on Eestis iga üldlaulupeo kavas olnud palju - 34\% (1969) kuni 98\% (1928) - uusi laule, mida pole laulupeol enne lauldud. Kui tahetakse traditsiooni jätkata, kuidas peaksid tänapäeva peokorraldajad leidma ja looma uusi laule, mida lauljad tahaksid laulda? Mina ei tea. See on kunst, ja kunstniku tööd ei saa ratsionaalselt mõista ega plaani järgi arendada, eriti sellisel juhul, mil keegi parimatest spetsialistidest ei saa enne laulupidu öelda, millisest uuest laulust saab tõeline laulupeolaul (Jürgenson 2014: 88). Veel keerulisem on ennustada, millist laulu tulevikus tahetakse korrata ehk pärandiks vastu võtta, eriti kui ajad muutuvad. Ennustamise teeb alati raskemaks asjaolu, et jutt on tulevikust. Siin aga tasub võib olla uurida minevikku: kaks kõige loovamat eesti laulupidu, kus esimest korda lauldi laule, mida kunagi tuleviku ajastutel taheti korrata, toimusid aastatel 1923 (10 laulu) ja 1938 (15 laulu) - mõlemal puhul moodustasid need esmaesitused, mis pärast said pärandilauludeks, ligikaudu kolmandiku kontserdi programmist. Eesti esimese vabariigi ajastu oli selles mõttes kõige loovam: 133 esmaesitusest 39 (29\%) korrati nõukogude või taasiseseisvuse ajajärgu pidudel. Lätis on numbrid ja protsendid sarnased: 112 vabariigiaja esmaesitusest 31 (28\%) korrati järgmistel ajastutel. Leedus korrati uusi laule harvem; hiljem korrati vaid 14 esimese vabariigi ajastul esitatud 73 laulust (19\%). 
Tavapärase laulupeo kavas muidugi pole ainult uued laulud; korratakse ka endiste pidude laule. Sellises mõttes oli Eestis pärandile enim orienteeritud 1969. aasta - juubeliaasta, mil vanad laulud moodustasid 66\% repertuaarist. Samalaadsed minevikupärandi taastamise kavad olid aastatel 1990 (47\% varasemate pidude laule) ja 2014 (49\%). Nende kolme peo kavad olid spetsiaalselt orienteeritud minevikupärandile; kas seda saaks nimetada konservatiivsuseks või mitte, polegi võib-olla tähtis - pärandi otsimine, taastamine või loomine oli kavade valijate eesmärk. On tunda, et alates 1980. aastast saadik on kavad muutunud veidi konservatiivsemaks kui eelnevatel aastatel - vist on pärandihimu muutunud viimastel aastakümnetel tugevamaks (joonis 3).

Küsimus, missuguseid laule erinevate ajastute pidudel korrati, täpsustab seda, kuidas valisid oma pärandi minevikuinimesed. Selle protsessi dokumenteerimine ehk traditsiooni inventari komplekteerimine on üks laulupidude tunnustusega seotud ülesanne UNESCO maailma vaimse kultuuri pärandi nimekirjas. Viimasel ajal uurivad folkloristid tavaliselt seda, kas UNESCO tunnustus on või pole mõjutanud nimekirja pandud kultuure, ja kirjeldavad, kuidas pärast UNESCO nimekirja panemist defineeritakse pärandit igal maal eraldi (Foster 2015). Aga peokorraldajatel on veelgi aktuaalsem küsimus: mida konkreetselt võtta minevikult, mida säilitada olevikust ja mida anda edasi tuleviku põlvkondadele. Selles praktilises ülesandes UNESCO vaikib; pärandiks võib olla see, mida kohalikud inimesed tunnustavad pärandina (UNESCO n.d.: 5). Näiteks kui mu kodulinnas Seattle'is 1981. aastal sündinud komme - inimlaine - tuli mõned aastad tagasi vägevail vooludel üle Eesti-, Läti- ja Leedumaa, võeti see vastu kui teretulnud laulupeo-innovatsioon, mitte kui globaalse kultuuri manifestatsioon (Maatee 2014: 34). Ja kui tuleviku laululava võtaks vastu räpp-laule (Kaljuste 2014: 105), jääksid ka need võimalikuks laulupeopärandiks. Ja muidugi see on hea, sest laulupidu on elav, alati taastav protsess ja pärand.

Käesolevas laulupidude laulutraditsioonide analüüsis püüdsin fikseerida, milline oli pärand mineviku pidudel, ehk kuidas ja mida omal ajal võeti minevikust. Traditsiooni kirjeldus näitab, et ka tulevikus on pidude korraldajatel kava valimisel vabad käed: peol saab laulda palju vanu laule (Leedu 2009 üldlaulupeol korratud laule oli isegi 75\%), saab ka enne lauldud laule kõrvale jätta ja ette võtta $98 \%$ uut repertuaari, nii nagu oli Eestis 1928. aastal. Selline ongi traditsiooni vaim, millest tuletatakse pärand. 


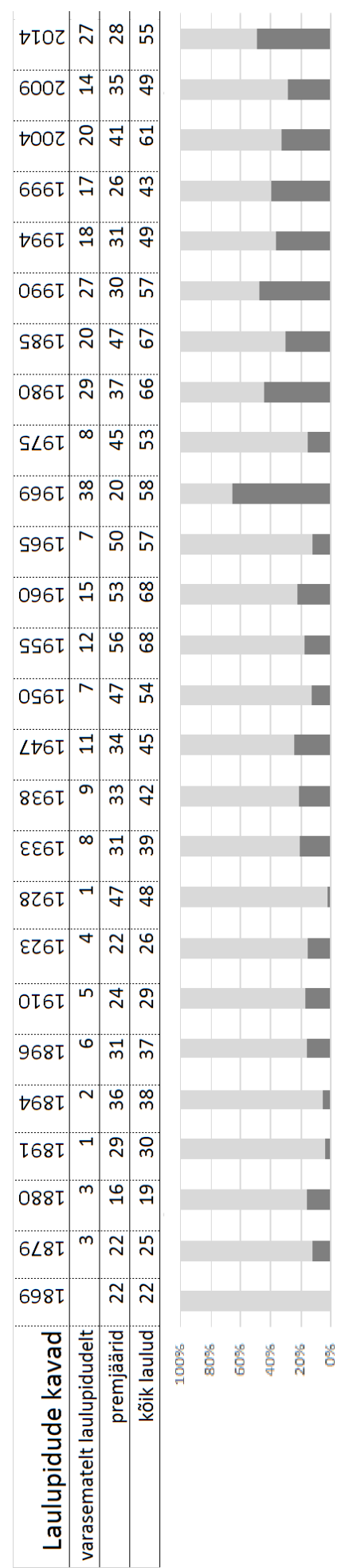

Joonis 3. Eesti üldlaulupidude kavad: uued laulud (esimene kord laululaval) ja lauldud varasematel laulupidudel. 


\section{Soovi(ta)tud laulupidude vaimne pärand maailmas}

Siin esitan kolm mõtet Baltimaade laulupidude kohast maailma vaimses kultuuripärandis.

1. Laulupidude pärand on regionaalne, ühine Baltimaade pärand. Ja mitte ainult sellepärast, et nii on kirjutatud UNESCO dokumendis. See tõesti ongi tõsi. Piisab ainult näha - kas minu silmaga väljastpoolt või teie omaga seestpoolt, et leedu ja läti ja eesti laulupidu on omavahel lähedased, ja samaviisi kaugemal sõbralikult populaarsest rootsi allsångist või põnevast vene suurkoori etendusest Sotši olümpiamängudel. Baltimaade pidudel on ühised juured. Algse üldise eeskuju andsid muidugi Euroopa saksa kooriliikumise peod Šveitsis, Preisimaal ja Vene impeeriumi Balti kubermangudes. Aga konkreetsem algus paistab siis, kui meenutada, et 19. sajandi Valga seminari juht Jānis Cimze oli aukülaline mõlemal Eesti ja Läti peol, sest paljud dirigendid ja heliloojad olid ju ta õpilased. Hiljem tuli Eesti laulupeole aukülalisena Peterburi Muusika akadeemia professor, eesti, läti ja leedu heliloojate õpetaja Jāzeps Vìtols, kelle pärandit pole seni veel Baltikumis piisavalt uuritud. Ja veel paar näidet ühisest ajaloost: esimene Baltimaade meeskooride laulupidu toimus Tartus, esimene Baltimaade segakooride laulupidu Riias, esimene Baltimaade (ehk Pribaltika) nõukogude laulupidu Vilniuses. Kes ees, see mees. Aga polegi tähtis, kes esimene, sageli kutsuti üksteist külla ja vaadati, mis teevad naabrid.

Ja poolteist sajandit kestnud kõrvuti arenemise resultaat saabki selgeks. Sellest rääkis näiteks Veljo Tormis Läti laulupeol aastal 1990, pärast Tormise lätikeelse laulu "Trīs zvaigznes" (Kolm tähte) etendust:

Kolm tähte. Kolm õde. Kolm laulupidu.

Üks mure. Üks lootus. Üks vabadus.

Ühte käigu meie hääl, ühte sündigu südamed, ühte laulud laugenegu.

Kuidas eestlaste, lätlaste ja leedulaste lauluhääl saab nende kolmes keeles ühte käia, on raskem konkreetselt ette kujutada, aga nähtavasti on seda võimalik südames tunda. Ühist balti repertuaari ei ole. Minu teada on ainult üks laiemalt levinud üldine balti laul, mida tunnevad kolm rahvast - selle laulva revolutsiooni laulu refrääni lauldi aastal 2014 Leedu laulupeo kulminatsioonis (enne Leedu riigihümni):

Ärgake Baltimaad, ärgake Baltimaad, Leedumaa, Lätimaa, Eestimaa! ${ }^{5}$

Kuigi lätlased ja eestlased ei ole üldlaulupeol kunagi seda laulu laulnud, mäletavad nad seda vist siiski ja saavad aru, miks Leedus lauldi seda laulu Balti keti 
25. aastapäeval. Kaasaegne regionaalne balti identiteet on mõnikord tugevam, mõnikord nõrgem, mõnikord lauldakse naabrite laule üldlaulupeol, mõnikord mitte. Et kestaks laulupeo balti pärandi tunne, ei pea eestlased vist laulma seda “Ärgake Baltimaad” või läti ja leedu laule. Piisab teadmisest, et lätlased või leedulased saavad oma keeles lauldes väljendada ka eestlaste tundeid, kui ka eesti keeles seda konkreetset laulu kunagi ei laulda. Näiteks 2015. aastal laulis Renārs Kaupers (Eestis populaarseima läti rokkbändi Prāta Vētra liige) Läti koolinoorte laulupeo lõppkontserdil oma lätikeelse laulu sooloosa:

Need on sõnad minu rahvalt, ja sellelt on ka mul laul, Ja tean, seda keegi mu asemel ei laula.

Ingliskeelses tõlkes ei helise see laul niimoodi kui eesti või leedu keeles. Vist on midagi laulupeopärandi kolmekeelsest, ühemeelsest vaimust arusaadav vaid Baltimaade elanikele, Baltimaade keeltes?

2. Laulupidude pärand maailmas käib üheskoos laulva revolutsiooni pärandiga. Sõnad, mis 1988. aastal kirjutas Heinz Valk, ei vanane: "Rahvas, kes lauldes ja naerdes revolutsiooni teeb, peaks olema õilsaks eeskujuks kõigile.” Öölaulupidu aastal 1988, Baltimaade taasiseseisvuse kuulutused ja üldlaulupeod 1990 ja baltlaste vägivallatu võit Nõukogude Liidu vägivalla üle suvel 1991 jäägu kui üks peatükk vägivallatu poliitika rahvusvahelisse ajalukku (Ackerman \& Duvall 2000; Sharp 2005). Selle ajaloo igas peatükis - kas see toimus Indias, Ameerika Ühendriikides, Leedus, Lõuna-Aafrikas või Myanmaris - toimus ime, ja need imed ükshaaval vaimustavad ja innustavad tulevikus vägivallatuid inimesi.

Ühest küljest ei sõltu see pärand enam eestlastest, lätlastest ja leedulastest ega nende mälust. Mulle meenub mõne aasta tagune jutuajamine lennukis ühe indialasega. Küsisin, mis tema arvab Mohandas Gandhist. "Ai, Gandhi," ütles ta, "kes temast tänapäeval mõtleb? Meil Indias on korruptsioon, vaesus, Gandhi ajad on ammu läbi." Tal oli ükskõik, et tema kaasmaalase ideid ja tegusid uuritakse ja mäletatakse maailmas veel kaua. Aga tahaks, et siinmaalgi kestaks mälestus sellest, mida baltlased on andnud maailmale - mõte, et laul on kilp ja relv, millega saab vastase inimese rinda ja südamesse pääseda ilma teda haavamata. See ongi laulupeo vaimne pärand.

3. Maailmas unikaalse muusikariista pärand. Teame ju, et Stradivari viiulil ei ole maailmas sarnast. Seda tuleb säilitada. Kuid kui vana ja habras ta ka poleks, seda ei panda muuseumisse klaasi taha, sest selleks, et muusikariist säiliks, tuleb sellel mängida. Eesti rahvusmuusika sümboliks peetakse kannelt. Aga 
laulupeo dirigendi ees on samuti unikaalne muusikariist, mida ta mängib - see on nii vaimne kui ka materiaalne instrument, mida laulupeol kehastab 30000 inimest, eesti rahvuskultuuri tuum. Seda riista tuleb mitte ainult säilitada, taastada ja mängida, vaid seda tuleb kaitsta ka füüsiliselt kui tarvis, et hoida ja jätta maailma tulevikupõlvkondadele pärandiks. Kusagil Baltikumist väljaspool pole võimalik osa võtta sellisest poolteist sajandit vanast, alati noorendavast (74-84\% innovatiivsest) unikaalsest muusikainimeste - lauljate, dirigentide, heliloojate ja publiku - üheksolemisest. Ja see muusikapärand on inimestel sel kuumal ajastul hädavajalik (Glassie 2014: 78).

\section{Kommentaarid}

1 Ettekanne konverentsil "Eesti kultuuri suurpeod maailmapärandis" Tallinna Ülikoolis 14. septembril 2015. Uurimistööd suvel 2014 toetas Eesti Instituudi Estophiluse stipendium. Tänan Triinu Ojamaad mustandile tehtud kommentaaride eest.

${ }^{2}$ Laulude nimekirjad on komplekteeritud raamatutest (Ojaveski 2002, Mikutavičius et al. 2014, Bērzkalns 1965), laulupidude korraldajate kodulehtedest ja trükitud programmidest.

3 Läti: Jānis Cimze, "Rīga dimd!" (esimest korda lauldud 1873); Emilis Dārziṇš, "Mēness starus stīgo" (1910); Andrejs Jurjāns, "Pūt vējiniı" (1910); Ernests Vīgners, "Strauja upe" (1888); Jāzeps Vìtols, "Beverīnas dziedonis" (1895) ja "Gaismas pils" (1910). Leedu: Mikalojus Čiurlionis, "Šèriau žirgelį" (1924); Vincas Kudirka, "Tautiška giesmè" (1924); Česlovas Sasnauskas, "Kur bèga Šešupe" (1928); Juozas Tallat-Kelpša, "Tris dienas, tris naktis" (1924). Kõik leedu laulud olid ka hästi tuntud ja lauldud tsaariajal, kuid tollal leedu üldlaulupidusid veel ei korraldatud.

${ }^{4}$ Lätis ja Leedus on ka kolmas tüüpiliste laulude kategooria, millesse kuuluvad paljud traditsioonilised laulupeolaulud: vana ehk arhailine rahvalaul, mille põhisisu on maarahva elu ja maailm.

5 Tähendus on natuke erinev igas keeles: leedulased laulavad "Bunda jau Baltija..." mis eesti keeles oleks "Ärkab juba Baltimaa..." ja läti "Atmostas Baltija..." tähendab "Ärkab Baltimaa...”. 


\section{Kirjandus}

Ackerman, Peter \& Duvall, Jack 2000. A Force More Powerful: A Century of Nonviolent Conflict. New York: St. Martin's Press.

Bausinger, Hermann 1990. Folk Culture in a World of Technology. Translated by Elke Dettmer. Folklore Studies in Translation. Bloomington, Indiana: Indiana University Press.

Bērzkalns, Valentīns 1965. Latviešu dziesmu svētku vēsture, 1864-1940. Brooklyn, NY: Grāmatu Draugs.

Brüggemann, Karsten \& Kasekamp, Andres 2014. 'Singing oneself into a nation’? Estonian song festivals as rituals of political mobilisation. Nations and Nationalism 20 (2), lk 259-276 (doi: 10.1111/nana.12059).

Dégh, Linda 1994. American Folklore and the Mass Media. Bloomington, Indiana: Indiana University Press.

Foster, Michael Dylan (toim) 2015. Special Double Issue: UNESCO on the Ground: Local Perspectives on Global Policy for Intangible Cultural Heritage. Journal of Folklore Research. An International Journal of Folklore and Ethnomusicology 52 (2-3).

Glassie, Henry 2014. War, Peace and the Folklorist's Mission. Journal of American Folklore 127 (503), lk 72-81 (doi: 10.5406/jamerfolk.127.503.0072).

Gudelis, Regimantas 2001. Chorinis menas lietuviu tautos kultūroje. Mokslinè monografija. Klaipėda: Klaipėdos Universiteto Leidykla.

Jürgenson, Heli 2014. Laulupidu ja repertuaar. Kaunimad laulud pühendan sull'. Tamm, Saari \& Ratas, Peep (koost). Ühesmõtlemine: "Laulu- ja tantsupeo puudutus ajas”. 24.-25. oktoober 2013. Tallinn: Eesti Laulu- ja Tantsupeo SA, lk 85-91.

Kaljuste, Tõnu 2014. 'Laulupidu ja Šveitsi kellad'. Tamm, Saari \& Ratas, Peep (koost). Ühesmõtlemine: Laulu- ja tantsupeo puudutuse ajas. 24.-25. oktoober 2013. Tallinn: Eesti Laulu- ja Tantsupeo SA, lk 104-105.

Kuutma, Kristin 1996. Laulupeod rahvusliku identiteedi kandjana. Mäetagused 1\&2 (doi:10.7592/MT1996.01/02.internet).

Lak̦e, Anda 2014. Dziesmu un deju svētku saglabāšana un attīstība, 2014.-2018. gads. Dziesmu un deju svētku (2013) dalībnieku aptaujas dati. PowerPoint presentation, n.p.

Lauristin, Marju 2014. Sotsioloogiline uuring 'Minu laulu- ja tantsupidu'. Tamm, Saari \& Ratas, Peep (koost). Ühesmõtlemine: Laulu- ja tantsupeo puudutuse ajas. 24.-25. oktoober 2013. Tallinn: Eesti Laulu- ja Tantsupeo SA, lk 40-63.

Maatee, Aet 2014. Laulu- ja tantsupidude partituur. Tamm, Saari \& Ratas, Peep (koost). Ühesmõtlemine: Laulu- ja tantsupeo puudutuse ajas. 24.-25. oktoober 2013. Tallinn: Eesti Laulu- ja Tantsupeo SA, lk 20-39. 
Mikutavičius, Juozas (toim) 2014. Lietuvos dainu švenčiu tradicija. The Tradition of Lithuanian Song Celebrations. n.p.: Dainų švenčių fondas, Lietuvos liaudies kultūros centras.

Muktupāvels, Valdis 2015. Latvian Nationwide Song (and Dance) Tradition: Identity of Tradition. Ettekanne. 11 $1^{\text {th }}$ Conference on Baltic Studies in Europe "Traditions. Transitions. Transfers", Marburg 7.-10. september 2015.

Ojaveski, Toivo \& Põldmäe, Alo \& Puust, Mart (koost) 2002. 130 aastat eesti laulupidusid. n.p.: Talmar \& Põhi kirjastus.

Sharp, Gene 2005. The New Challenge. Škapars, Jānis (toim). The Baltic Way to Freedom: Non-Violent Struggle of the Baltic States in Global Context. Rīga: Zelta Grauds, lk 423-426.

Szwed, John 2015. Whatever Happened to Folksongs? Francis Lee Utley Memorial Lecture. American Folklore Society Annual Meeting, October 16, 2015.

UNESCO [2012]. Mis on vaimne kultuuripärand? [Tallinn]: UNESCO Eesti Rahvuslik Komisjon.

Valk, Heinz 1988. Laulev revolutsioon. Sirp ja Vasar 17 juuni, lk 3.

Wilgus, D. K. 1973. The Text Is the Thing. Journal of American Folklore 86, lk 241-252 (doi: 10.2307/539153). 


\title{
Summary
}

\section{Traditions and heritage of Baltic song celebrations}

\author{
Guntis Šmidchens
}

Keywords: heritage, song celebrations, songs, tradition

An overview of all the 1,973 songs that have appeared in seventy Estonian, Latvian, and Lithuanian national song celebration programmes from 1869 to the present day reveals a richly innovative, creative tradition: in each of the three festival repertoires, 74-84 percent of the songs were performed only once over the entire history of the national celebrations. When concert participants choose to repeat songs sung in previous years, they identify these songs as heritage. Sometimes, most notably in the retrospective Estonian programmes of 1969 and 2014, a large portion of the concert repertoire was repeated from the past. The tradition as a whole, however, is not necessarily pastoriented. Some celebrations have turned away from heritage. In the 1928 Estonian celebration, for example, only 2 percent of the programme (only one song) had ever been sung in an earlier celebration. This, too, is a heritage of song celebrations: future organisers are free to decide how many, if any, songs they wish to repeat from earlier festivals. The song festival tradition allows both innovative and conservative choice of repertoire at any given festival. 